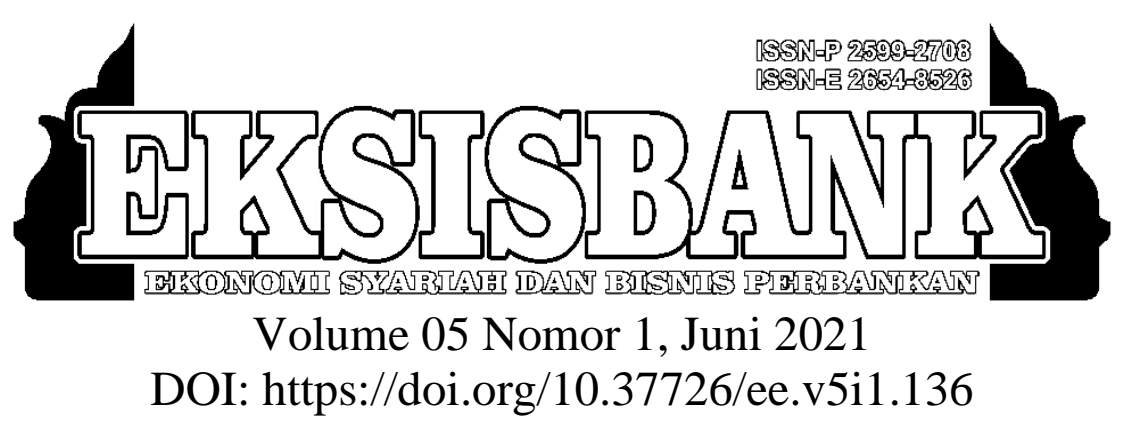

\title{
Analisis Praktek Akad Qardhul Hasan Dalam Perspektif Ekonomi Syari'ah Di Koperasi Dewan Kemakmuran Masjid At-Taqwa Desa Cicadas Sagalaherang Kabupaten Subang
}

\author{
Mita Nurul Hidayati ${ }^{1}$, Ahmad Damiri $^{2}$, Jalaludin ${ }^{3}$ \\ ${ }^{1}$ Sekolah Tinggi Agama Islam (STAI) Riyadhul Jannah Subang \\ ${ }^{1}$ mitanurulhidayati@gmail.com \\ ${ }^{2}$ Universitas Islam Negeri (UIN) Sunan Gunung Djati Bandung \\ 2ahmad.damiri86@gmail.com \\ ${ }^{3}$ Sekolah Tinggi Ilmu Ekonomi Syariah (STIES) Indonesia Purwakarta \\ 3jalaludinstiesip@gmail.com
}

\begin{abstract}
ABSTRAK
Koperasi pada umumnya merupakan lembaga pembiayaan yang menerima simpanan dan pinjaman untuk pembiayaan, dengan menghimpun dana dari para anggotanya yang kemudian dana tersebut disalurkan kembali kepada para anggota atau masyarakat umum. Penelitian ini bertujuan untuk menganalisis penerapan pembiayaan Qardhul Hasan dalam perspektif Ekonomi Syariah yang dilaksanakan di Koperasi Dewan Kemakmuran Masjid At-Taqwa Desa Cicadas Kecamatan Sagalaherang Kabupaten Subang. Qardhul Hasan memiliki arti yaitu pinjaman yang baik, Produk Qardhul Hasan merupakan penawaran pembiayaan kepada nasabah yang akan digunakan untuk usaha mikro, kemudian anggota mengembalikan angsuran sesuai dengan nominal yang dipinjam pada waktu yang telah ditentukan, dan penting sekali kita mengkaji bagaimana penerapan Qardhul Hasan dalam perspektif ekonomi syariah, karena pinjam meminjam merupakan salah satu bagian dari kehidupan kita didunia. Penelitian ini bertujuan untuk mengetahui bagaimana ketentuan dan penerapan akad Qardhul Hasan, perspektif ekonomi syari'ah terhadap akad Qardhul Hasan dan dampak akad Qardhul Hasan terhadap masyarakat. Jenis penelitian ini adalah kualitatif dengan menggunakan metode deskriptif analisis. Sumber data yang digunakan meliputi data primer dan sekunder. Adapun hasil analisis diketahui bahwa pelaksanaan akad Qardhul Hasan di Koperasi Dewan Kemakmuran Masjid At-Taqwa Desa Cicadas sesuai dengan syariat islam. Hal ini nampak dimana pihak koperasi memberikan pinjaman tanpa adanya tambahan. Dalam akad Qardhul Hasan di Desa Cicadas terdapat pembiayaan macet. faktornya yaitu, pertama, karena
\end{abstract}


kurangnya pengarahan dan bimbingan dari pihak koperasi. Kedua, karena kelalaian anggota itu sendiri. Dampak yang anggota rasakan yaitu sangat membantu untuk biaya modal usaha, sekolah, kesehatan.

Kata kunci-Akad Qardhul Hasan, Koperasi Dewan Kemakmuran Masjid, Perspektif Ekonomi Syariah.

\begin{abstract}
Cooperatives are generally financial institutions that accept deposits and loans for financing, by collecting funds from their members which are then channeled back to members or the general public. This study aims to analyze the application of Qardhul Hasan financing in the perspective of Islamic Economics carried out at the At-Taqwa Mosque Prosperity Council Cooperative, Cicadas Village, Sagalaherang District, Subang Regency. Qardhul Hasan has the meaning of a good loan, the Qardhul Hasan product is a financing offer to customers that will be used for micro businesses, then members return installments according to the nominal borrowed at a predetermined time, and it is very important that we examine how the implementation of Qardhul Hasan in perspective Islamic economics, because lending and borrowing is one part of our lives in the world. This study aims to find out how the provisions and implementation of the Qardhul Hasan contract, the sharia economic perspective on the Qardhul Hasan contract and the impact of the Qardhul Hasan contract on the community. This type of research is qualitative using descriptive analysis method. Sources of data used include primary and secondary data. The results of the analysis show that the implementation of the Qardhul Hasan contract at the At-Taqwa Mosque Prosperity Council Cooperative in Cicadas Village is in accordance with Islamic law. This can be seen where the cooperative provides loans without any additional. In the Qardhul Hasan contract in Cicadas Village there is nonperforming financing. the factors are, first, because of the lack of direction and guidance from the cooperative. Second, because of the negligence of the members themselves. The impact that members feel is very helpful for business capital costs, schools, health.
\end{abstract}

Keywords - Sharia Economic Perspective, Qardhul Hasan Agreement, Cooperative Council of Mosque Prosperity.

\section{PENDAHULUAN}

Dalam syariat Islam hubungan antar manusia dengan manusia disebut sebagai muamalah. Muamalah dalam islam merupakan kegiatan yang mengatur hal-hal yang berhubungan dengan kehidupan manusia, kegiatan tersebut mencakup diantaranya jual beli, sewa menyewa, utang piutang dan lain sebaginya. Segala bentuk muamalah yang dilakukan harus dengan prinsip tolong menolong, dan bernilai kebaikan. Seiring meningkatnya kebutuhan perekonomian yang semakin banyak dan berkembang, sedangkan kemampuan untuk mencapai sesuatu yang diinginkan tersebut terbatas, maka hal ini menyebabkan manusia yang hidup berdampingan saling memerlukan bantuan dari manusia lain demi mencukupi kebutuhan hidupnya. Kebutuhan tersebut sangat beragam, baik dari kebutuhan primer, sekunder dan tersier. Untuk memperoleh semua itu manusia perlu berinteraksi, bekerjasama dan saling tolong-menolong, karena pada hakikatnya dalam memenuhi kebutuhan hidup seseorang tidak bisa melakukan sendiri tanpa pertolongan dan bantuan dari orang lain. Interaksi sosial adalah proses sosial yang berkaitan dengan cara 
berhubungan antara individu dan kelompok untuk membangun sistem dalam hubungan social (Suskendariani 2019).

Islam sebagai agama yang mengatur segala urusan dalam kehidupan manusia, juga mengatur mengenai perkara utang-piutang atau simpan pinjam. Pinjam meminjam dalam Islam pengertiannya adalah akad, yaitu perjanjian memberikan manfaat, tanpa mengurangi nilai barang atau uang yang dipinjamkan setelah dikembalikan. Pada dasarnya, urusan pinjam meminjam dalam Islam tidak diperbolehkan adanya bunga maupun praktek riba.

Pembiayaan merupakan perjanjian antara pihak yang satu dengan pihak yang lainnya dan objek yang diperjanjikan pada umumnya adalah uang (Az-zarqa and Hidayah 2018). diatur dalam Bab ketiga belas, Buku ketiga KUH Perdata, Pasal 1754, menyebutkan bahwa: Pembiayaan adalah perjanjian dengan mana pihak yang satu memberikan kepada pihak yang lain suatu jumlah tertentu barangbarang yang habis karena pemakaian, dengan syarat bahwa pihak yang belakangan ini akan mengembalikan sejumlah yang sama dari macam dan keadaan yang sama pula. Praktek pembiayaan akad Qardhul Hasan dalam literatur fiqih termasuk ke dalam akad tabarru (sosial) karena di dalamnya terdapat unsur saling tolong-menolong dalam hal kebaikan dan ketakwaan bukan akad tijarah (komersial) (Rozalinda 2016). Dalam QS. Al-Maidah (5): 2 ditegaskan:

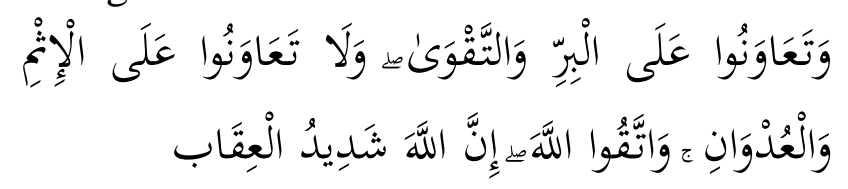

"Dan tolong-menolonglah kamu dalam (mengerjakan) kebajikan dan takwa, dan jangan tolong-menolong dalam berbuat dosa dan pelanggaran. Dan bertakwalah kamu kepada Allah, sesungguhnya Allah amat berat siksa-Nya"
Ayat di atas menjelaskan supaya kita saling tolong-menolong dijalan yang baik dan takwa, serta melarang kita untuk saling tolongmenolong dalam berbuat dosa dan saling bermusuhan. Memberi bantuan pinjaman uang atau modal kepada orang yang membutuhkan mempunyai nilai kebaikan dan pahala disisi Allah SWT. Dalam syariat Islam praktek utang piutang adalah salah satu transaksi muamalah yang diperbolehkan oleh para ulama berdasarkan hadis riwayat Ibnu Majah dan ijma ulama (Muhammad Syafi'i Antonio 2001). Akan tetapi dengan adanya teori yang memperbolehkan praktek Qardhul Hasan seringkali terdapat suatu kelompok masyarakat atau individu yang menyalahgunakan dan memanfaatkan keadaan tersebut untuk mencari keuntungan. Padahal maksud dan tujuan dari akad Qardhul Hasan ini adalah untuk saling tolong menolong, mendatangkan kemaslahatan antar sesama manusia, bukan untuk mencari keuntungan serta eksploitasi (Lestari 2020). Kasus tersebut dapat kita jumpai pada anggota Koperasi Dewan Kemakmuran Masjid AtTaqwa Desa Cicadas, Kecamatan Sagalaherang, Kabupaten Subang. Kemudian, yang menjadi fokus dalam penelitian ini adalah anggota yang beroperasi di bidang UMKM. Dimana beberapa dari anggota tersebut melakukan pembiayaan macet.

Selain digunakan untuk usaha, dana tersebut juga digunakan untuk membantu anggotanya yang sedang sakit, sumbangan sukarela untuk anggota keluarga anggota yang meninggal dunia dan sumbangan syawalan di hari idul fitri (Hamidah, Jalaludin, and Damiri 2019). Tetapi seiring berjalannya waktu dan mengingat bahwa tidak setiap hari terdapat anggota yang sakit atau memerlukan bantuan, maka mereka melakukan terobosan baru guna memproduktifkan uang yang ada agar berkembang dan bermanfaat yaitu dengan cara melakukan praktek pembiayaan dan 
pihak yang berhutang harus mengembalikan utang tersebut sesuai dengan nominal pinjaman.

Adapun hasil observasi dan wawancara dengan ketua Koperasi Dewan Kemakmuran Masjid At-Taqwa yang bernama Bapak Haeri pada hari Rabu, 17 Juli 2019 bertempat Koperasi Dewan Kemakmuran Masjid AtTaqwa Cicadas Sagalaherang Subang dengan hasil bahwa berawal dari tujuan pendirian dan Misi Koperasi tersebut yaitu menjadi Koperasi yang mandiri dalam ekonomi membangun desa dengan menerapkan prinsip-prinsip Syariah. Salah satu faktor pendukung agar pengembangan ini berasal adalah permodalan yang kuat. Dengan adanya permodalan yang kuat serta mencukupi untuk pengembangan usaha maka diharapkan adanya peningkatan keuntungan sehingga secara tidak langsung akan mengangkat kesejahteraan anggota maupun keluarga anggota serta masyarakat luas (Haeri 2019). Dari hasil observasi, melihat kondisi di dilapangan dengan permasalah yang terjadi dilingkungan wilayah tersebut. Tentunya akad qardhul hasan yang di implementasikan lembaga koperasi menajadi solusi guna membantu perekonomian masyarakat di wilayah tersebut, sehingga beberapa anggota UMKM yang memiliki pembiayaan macet dapat terbantu dengan adanya akad qardhul hasan, begitupun dengan beberapa bantuan sosial lainnya seperti membantu anggotanya yang sedang sakit, sumbangan sukarela untuk anggota keluarga yang meninggal dunia dan sumbangan syawalan di hari idul fitri. Sehingga fokus masalah dalam penelitian ini adalah bagaimana implementasi akad qardhul hasan dalam perspektif ekonomi islam di Koperasi Dewan Kemakmuran Masjid AtTaqwa Desa Cicadas Sagalaherang Kabupaten Subang.

Tujuan Penelitian : Untuk mengetahui bagaimana ketentuan dan pelaksanaan praktek akad Qardhul Hasan di Koperasi Dewan Kemakmuran Masjid At-Taqwa Cicadas Sagalaherang Subang, untuk mengetahui bagaimana perspektif ekonomi syariah pada praktek akad Qardhul Hasan di Koperasi Dewan Kemakmuran Masjid AtTaqwa Cicadas Sagalaherang Subang dan untuk mengetahui bagaimana dampak praktek akad Qardhul Hasan terhadap masyarakat di Desa Cicadas Kecamatan Sagalaherang Kabupaten Subang.

\section{TINJAUAN PUSTAKA}

Qardh hasan adalah perjanjian qardh (pinjaman) yang khusus untuk tujuan sosial. Qard hasan adalah suatu interest free financing. Kata hasan adalah kata Bahasa Arab ialah ihsan yang berarti kebaikan kepada orang lain (Arief 2012). Qard hasan atau qardhul hasan berarti beneficial loon atau benevolent loan, yaitu pinjaman yang diberikan kepada pihak yang sangat memerlukan untuk jangka waktu tertentu tanpa harus membayar bunga/keuntungan. Dan penerima qard hasan hanya diharuskan untuk melunasi jumlah pinjaman semula tanpa diharuskan memberikan tambahan apa pun.

Qardhul hasan adalah pinjaman tanpa adanya imbalan yang memungkinkan peminjam untuk menggunakan dana tersebut selama jangka waktu tertentu dan mengembalikan dalam jumlah yang sama pada akhir periode yang disepakati (Qardhawi 1993). Dari beberapa devinisi diatas, beberapa pakar ekonomi mendevinisikan tentang akad qardhul hasan, salah satu diantaranya :

Menurut Sri Nurhayati dan Wasilah qardhul hasan adalah pinjaman tanpa dikenakan biaya (hanya wajib membayar sebesar pokok hutangnya), pinjaman uang seperti inilah yang sesuai dengan ketentuan Syariah (tidak ada riba), karena kalua meminjamkan uang maka ia tidak boleh meminta pengembalian yang 
lebih besar dari pinjaman yang diberikan (Muhamad Bisri Mustofa and Mifta Khatul Khoir 2019). Sedangkan Ahmad Ifham Sholihin dalam buku pintar ekonomi syariah menyebutnya sebagai qardh al-hasan atau pinjaman kebijakan adalah yang pertama, pinjaman dengan kewajiban pengembalian pinjaman pokoknya saja, tanpa imbalan apa pun. Yang kedua, suatu akad pinjammeminjam dengan ketentuan pihak yang menerima pinjaman tidak wajib mengembalikan dana apabila terjadi force majeure.

Dapat disimpulkan qardhul hasan adalah perjanjian hutang dengan syarat bahwa penerima pinjaman hanya membayar pokok hutangnya saja tanpa ada tambahan apapun ketika mengembalikan/ membayarkan hutang tersebut.

Dalam ekonomi/keuangan syariah, qardhul hasan adalah pinjaman yang tidak mengambil manfaat (keuntungan) apapun namun tetap ditentukan untuk dibayarkan kembali. Produk/ skema ini merupakan salah satu produk/skema sistem keuangan Syariah yang sangat penting dalam mendukung pemulihan atau menopang perekonomian.

Penelitian tentang Analisis Praktek Akad Qardhul Hasan Dalam Perspektif Ekonomi Syari'ah Di Koperasi Dewan Kemakmuran Masjid sudah banyak dilakukan penelitian oleh peneliti sebelumnya, seperti penelitianpenelitian berikut ini:

1. Konsep Koperasi Bung Hatta Dalam Perspektif Ekonomi Syariah (Efendi and Bakhri 2018)

Penelitian ini dilatarbelakangi oleh belum banyaknya tokoh ekonomi Indonesia yang berkontribusi dalam perkembangan ekonomi syariah. Bung Hatta merupakan salah satu tokoh intelektual di bidang ekonomi yang mencurahkan idenya untuk kemajuan bangsa. Konsep koperasi merupakan bukti keprihatinan Bung Hatta akan kondisi ekonomi masyarakat Indonesia yang terjebak hutang oleh lintah darat. Konsep koperasi yang ditawarkan oleh Bung Hatta merupakan bentuk modern dari adat istiadat dan tradisi masyarakat Indonesia, yaitu semangat kolektivisme (gotong royong dan tolong menolong). Konsep tersebut diduga memiliki keterkaitan dengan konsep ekonomi syariah. Adapun yang menjadi perumusan masalah dalam penelitian ini adalah bagaimana konsep koperasi Bung Hatta dalam perspektif ekonomi syariah. Tujuan penelitian ini adalah untuk mengetahui konsep koperasi Bung Hatta dalam perspektif ekonomi syariah. Subjek penelitian ini adalah Bung Hatta. Sementara objek dalam penelitian ini adalah konsep koperasi Bung Hatta dalam perspektif ekonomi syariah. Jenis penelitian yang digunakan adalah jenis penelitian kepustakaan. Pendekatan yang digunakan melalui pendekatan filosofis dan komparatif. Teknik analisis data yang digunakan dalam penelitian ini yakni kualitaitif, yaitu dengan proses editing, klasifikasi, memberi kode, dan penafsiran. Penafsiran dilakukan dengan membandingkan konsep koperasi Bung Hatta dengan konsep ekonomi syariah. Hasil penelitian adalah terdapat persamaan konsep koperasi Bung Hatta dengan ekonomi syariah, yaitu pada akad, nilai-nilai dasar, prinsip tolong menolong, prinsip manfaat, prinsip mashlahah, fungsi, karakteristik, produksi, dan distribusi.

Perbedaan peneliti sebelumnya dengan peneliti saat ini adalah peneliti saat ini koperasi hanya dijadikan sebagai lokasi penelitian saja, bukan menkaji konsep koperasi Bung Hatta dalam pandangan ekonomi Syariah, melainkan mengkaji praktek Qardhul Hasan yang di praktekan di Koperasi DKM Mesjid At-Taqwa Subang dalam perspektif ekonomi Syariah. 


\section{Konsep Divisi Ekonomi Masjid Berbasis}

Teknologi Industri 4.0 (Ma'rifahYuliani 2019)

Dimasa lahirnya Islam, Masjid tidak berfungsi sebagai tempat ibadah sholat saja, melainkan sebagai tempat untuk urusan negara, politik, ekonomi atau lebih tepatnya disebut Masjid sebagai Pusat Ekonomi dan Peradaban Umat Islam. Ekonomi syariah tidak bisa hanya mengandalkan perbankan dan lembaga keuangan lainnya sebagai pusat ekonomi karena mereka diciptakan sebagai lembaga profit, tidak berorientasi untuk kepentingan umat. Masjid berfungsi sebagai tempat ibadah mnelainkan juga bisa digunakan sebagai pusat ekonomi mendirikan divisi ekonomi, dengan menyediakan sarana akad tabarru' (tolong menolong) yakni simpan pinjam menggunakan akad qardhul hasan, didukung teknologi revolusi industri 4.0 berbasis startup, masjid bisa sebagai pusat ekonomi yang hemat biaya yang berorientasi untuk kesejahteraan umat Muslim. Penelitian ini bertujuan mengembalikan masjid sebagai tempat pusat ekonomi, yakni bertemunya orang yang kuat secara ekonomi untuk membantu orang yang lemah, memberantas riba, menolong yang lemah ekonomi dengan menggunakan teknologi revolusi industri 4.0.

Perbedaan peneliti sebelumnya dengan peneliti saat ini adalah Masjid berfungsi sebagai tempat ibadah mnelainkan juga bisa digunakan sebagai pusat ekonomi mendirikan divisi ekonomi, dengan menyediakan sarana akad tabarru' (tolong menolong) yakni simpan pinjam menggunakan akad qardhul hasan, didukung teknologi revolusi industri 4.0 berbasis startup, masjid bisa sebagai pusat ekonomi yang hemat biaya yang berorientasi untuk kesejahteraan umat Muslim. Sedangkan pada peneliti saat ini koperasi yang menjadi lokasi penelitian dalam pengelolaannya masih belum di dukung dengan teknologi revolusi industry 4.0.
3. Qardh al-Hasan dalam Perbankan Syariah:

Konsep dan Implementasinya Berdasarkan

Prinsip Manfaat bagi Pemberdayaan Masyarakat (Purwadi 2011)

Qardh al-hasan adalah suatu sistem yang berkaitan dengan segala bentuk pinjaman tanpa imbalan yang berasaskan pada hukum al-qardh al hasan. Dalam literatur fikih klasik, konsep qardh al hasan dikategorikan dalam aqad tathawwi atau akad tolong menolong dan bukan transaksi komersial. Perjanjian ini dimasukkan ke dalam aqad tabarru', yaitu perjanjian transaksi nirlaba (not-for profit transaction). Apabila konsep ini diterapkan dalam Perbankan Islam maka kegunaan atau manfaat al-qardh al hasan dapat rasakan dan dinikmati oleh masyarakat melalui: Pertama, memahami konsep qardh al hasan secara tekstual dengan menggali nilai-nilai ilmiah dari ajaran Islam dan memperkaya persepsi masyarakat itu secara kontekstual dengan dimensi baru bahwa al-qardh al hasan merupakan suatu kekuatan yang memiliki dampak aktual terhadap kehidupan ekonomi umat Islam. Kedua, mengembangkan organisasi dan manajemen Perbankan Syariah secara profesional. Perorganisasian kegiatan al-qardh al hasan dilaksanakan melalui berbagai fungsi kelembagaan, seperti fungsi pengumpulan dan penyimpanan sumbersumber dana al-qardh al hasan, fungsi penyaluran, fungsi evaluasi, penelitian dan pengembanyan yang efektif.

Perbedaan peneliti sebelumnya dengan peneliti saat ini adalah peneliti terdahulu mengimplementasikan akad Qardhul Hasan pada Lembaga perbankan Syariah bukan pada Lembaga koerasi yang dikelola oleh DKM, Sedangkan pada peneliti saat ini lokasi penelitian merupakan Lembaga koperasi yang dikelola oleh DKM Mesjid, dimana koperasi tersebut masih menginduk pada koperasi yang ada di Desa setempat, namun pada 
pengelolaannya sudah mencoba menerapkan prinsip-prinsip Syariah.

4. Baitul Maal Wa Tamwil Sebagai Lembaga Keuangan Mikro Syariah Pemberdaya Ekonomi Umat (Konsep dan Teori) (Solekha et al. 2021)

Tujuan penelitian untuk menggali lebih dalam konsep dan teori Baitul Maal Wa Tamwil, karena dilatarbelakangi oleh kenyataan yang terjadi di lingkungan bahwa BMT telah menunjukkan keberhasilannya yang telah tersebar luas hampir di seluruh wilayah Indonesia, terbukti di Tahun 2016 mencapai 6000 unit BMT dan menemukan prospek yang baik. Jenis penelitian ini adalah kualitatif, didukung oleh data yang diambil secara sekunder dengan menggunakan studi kepustakaan. Untuk menunjang penelitian, penulis mengolah data menggunakan Ms. Excel. BMT adalah lembaga keuangan mikro syariah sebagai lembaga swadaya masyarakat yang menghimpun dan mengelola dana menurut prinsip syariah dalam rangka mencapai tujuan ekonomi keuangan dan kemanusiaan atau untuk mencapai mashlahah. BMT tidak hanya fokus pada kegiatan keuangan tetapi juga kegiatan kebajikan sosial. BMT mengacu pada sumber otoritatif Islam, UU No. 25 tahun 1992 tentang perkoperasian dan fatwa DSN-MUI. Sumber pembiayaan berasal dari pelanggan dan hasil pendapatan operasional. Dana nasabah kemudian dikelola dengan menggunakan pembiayaan dan akad syariah, keuntungannya dikenal dengan bagi hasil. BMT harus selalu melakukan evaluasi agar sistem operasional dan sumber dayanya lebih baik dan terus melakukan sosialisasi kepada masyarakat.

Perbedaan peneliti sebelumnya dengan peneliti saat ini adalah peneliti terdahulu meneliti Teori dan Konsep Lembaga BMT yang dianggap telah sukses menunjukkan keberhasilannya yang telah tersebar luas hampir di seluruh wilayah Indonesia, terbukti di Tahun 2016 mencapai 6000 unit BMT dan menemukan prospek yang baik. Sedangkan pada peneliti saat ini Lembaga koperasi yang dikelola oleh DKM Mesjid legalitas lembaganya masih belum Syariah karena masih menginduk ke Koperasi Desa, namun pada pengelolaannya sudah mencoba menerapkan prinsip-prinsip Syariah.

\section{Praktek Akad Qardhul Hasan Pada Bank Wakaf Mikro (Faujiah 2020) \\ Peningkatan kesejahteraan masyarakat} dilakukan oleh lembaga keuangan syariah dengan memberikan pembiayaan dana kebajikan dan melakukan program tanggung jawab sosial. Dana kebajikan atau akad Qardhul hasan dalam Lembaga Keuangan Syariah dikenal dengan akad pinjaman dana kepada nasabah dengan ketentuan bahwa nasabah wajib mengembalikan pokok pinjaman yang diterimanya pada waktu yang telah disepakati baik secara sekaligus maupun cicilan. Prosedur pembiayaan Qardhul Hasan yang diterapkan 21di Lembaga Keuangan Syariah serta bagaimana penyaluran pembiayaan Qardhul Hasan di Lembaga Keuangan Syariah, bertujuan untuk menyempurnakan kewajiban hubungan dengan Allah SWT, hubungan dengan manusia dan hubungan dengan alam sekitar dalam rangka menghasilkan pembangunan ekonomiguna meningkatkan kualitas kehidupan yang lebih baik. Dengan menggunakan metode Kuantitatif melalui teknik analisis, observasi dan dokumentasi untuk memperoleh sebuah kesimpulan. Pada umumnya sumber dana pembiayaan Qardhul Hasan melalui Zakat, Infaq, Shodaqoh yang berasal dari LAZNAS (Lembaga Amil Zakat Nasional) di Lembaga Keuangan Syariah. Penyaluran pembiayaan Qardhul Hasan di Lembaga Keuangan Syariah sudah terlaksana dengan tepat sasaran yaitu pihak yang 
mendapat pembiayaan Qardhul Hasan ini hanya masyarakat menengah kebawah yang memiliki Usaha Kecil dan Menengah (UKM) kerena dilakukan survei terlebih dahulu mengenai keadaan nasabah sebenarnya, pembiayaan Qardhul Hasan ini sudah sesuai dengan akad Qardh yaitu pembiayaan ini ditunjukan untuk sosial dan tolong menolong serta nasabah hanya wajib mengembalikan pokok pembiayaannya saja tanpa dikenai margin waqaf uang dapat membantu perkembangan bank-bank syariah, khususnya BPR Syariah. Keunggulan dana waqaf, selain bersifat abadi atau jangka panjang, dana waqaf adalah dana termurah yang seharusnya menjadi incaran bank-bank Syariah (bank wakaf mikro).

Perbedaan peneliti sebelumnya dengan peneliti saat ini adalah peneliti terdahulu meneliti Akad Qardhul Hasan Pada Bank Wakaf Mikro, dimana salah keunggulan dana waqaf, selain bersifat abadi atau jangka panjang, dana waqaf adalah dana termurah yang seharusnya menjadi incaran bank-bank Syariah (bank wakaf mikro). Sedangkan pada peneliti saat ini akad Qardhul Hasan yang di praktekkan pada Lembaga koperasi yang dikelola oleh DKM Mesjid ini sumber dananya masih varian tidak hanya dari sumber wakaf melainkan masih ada dari proses penghimpunan dana masyarakat dalam bentuk tabungan.

\section{Analisis Penerapan Pembiayaan Qardhul} Hasan Berdasarkan PSAK Syariah Pada BMT Al Ittihad Rumbai Pekanbaru (Suryadi and Putri 2018)

Penelitian ini bertujuan menganilisis penerapan pembiayaan Qardhul Hasan berdasarkan PSAK syariah pada BMT al Ittihad Rumbai Pekanbaru. Metode penelitian yang digunakan adalah metode penelitian kualitatif sebagai dasar penulisan bersifat deskriptif analisis. Dengan teknik pengumpulan data yaitu wawancara, mengumpulkan dokumen, serta menggunakan studi pustaka. Hasil penelitian ini menyimpulkan bahwa pelaporan pembiayaan Qardhul Hasan sudah sesuai dengan PSAK Syariah karena dananya berasal dari dana internal Yayasan YKPI sehingga tidak dipisahkan dari laporan neraca melainkan disajikan dalam laporan neraca. Namun pihak BMT tidak memisahkan sumber atau aliran dananya sehingga dapat diasumsikan pembiayaan Qardhul Hasan ini menggunakan dana dari Zakat, Infaq dan Sedekah(ZIS). Penerapan pembiayaan Qardhul Hasan hanya diperuntukkan bagi karyawan dan pegawai saja sehingga jauh dari referensi serta dalil tentang pembiayaan itu sendiri. Kemudian untuk perlakuan akuntansi Qardhul Hasan belum sepenuhnya sesuai dengan PSAK Syariah baik dalam pengakuan dan pengungkapan transaksi.

Perbedaan peneliti sebelumnya dengan peneliti saat ini adalah peneliti terdahulu meneliti Penerapan Pembiayaan Qardhul Hasan Berdasarkan PSAK Syariah Pada BMT Al Ittihad Rumbai Pekanbaru, dimana hasil penelitian perlakuan akuntansi Qardhul Hasan belum sepenuhnya sesuai dengan PSAK Syariah baik dalam pengakuan dan pengungkapan transaksi. Sedangkan pada peneliti saat ini akad Qardhul Hasan yang di praktekkan pada Lembaga koperasi yang dikelola oleh DKM Mesjid ini hanya melihat kesesuaian antara teori dengan kondisi praktek yang nyata di Koperasi DKM, tidak mengkaji akad Qardhul Hasan sesuai dengan PSAK Syariah baik dari segi pengakuan maupun pengungkapan transaksi.

7.Akad Qordhul Hasan Sebagai Sarana Pelaksanaan CSR Pada Perbankan Syariah (Arief 2012)

Qordhul Hasan adalah kegiatan penyaluran dana dalam bentuk pinjaman kebajikan tanpa 
imbalan dengan kewajiban pihak peminjam mengembalikan pokok pinjaman secara sekaligus atau cicilan dalam waktu tertentu. Dalam konteks kekinian qardhul hasan sendiri tidak berhenti pada paparan konsep belaka, namun tercermin dalam beberapa aplikasi perekonomian dan telah menjamur di perbankan Syariah. Maka penerapan CSR pada perusahaan dan instansi baik pemerintah dan swasta merupakan wadah dan sarana untuk qardhul hasan diterapkan dengan tujuan sosial yang besumberkan dari infaq, zakat, shadaqoh, denda dan juga sumbangan. Dan keutuhan akad qardhul hasan pun dalam Islam harus berlandaskan sempurnanya rukun, syarat, manfaat, fatwa bahkan jelas akan aplikasinya sehingga terbentuknya system control yang rapi bagi pelaku akad dan ekonom. Selaranya pula pegiat ekonomi melihat qardhul hasan menjadi respon korporat dalam transaksi di perbankan Syariah di era modern ini.

Perbedaan peneliti sebelumnya dengan peneliti saat ini adalah peneliti terdahulu meneliti Akad Qordhul Hasan Sebagai Sarana Pelaksanaan CSR Pada Perbankan Syariah, artinya akad Qardhul Hasan dijadikan sebagai jembatan jiwa sosial/tabarru'iyah-nya Lembaga perbankan dengan pihak masyarakat. Sedangkan pada peneliti saat ini akad Qardhul Hasan yang di praktekkan pada Lembaga koperasi yang dikelola oleh DKM Mesjid ini hanya melihat kesesuaian antara teori dengan kondisi praktek yang nyata di Koperasi DKM, bukan sebagai sarana menyalurkan CSR.

\section{Evaluasi Non Performing Loan (NPL)}

Pinjaman Qardhul Hasan (Studi Kasus Di

BNI Syariah Cabang Yogyakarta) (Adnan and Furywardhana 2006)

Qardhul-hasan merupakan salah satu produk pembiayaan yang disediakan oleh bank syariah. Berbeda dengan produk pembiayaan lainnya, qardhul-hasan memiliki karakteristik yang unik, antara lain untuk menghibur nasabah yang sangat spesifik yang dapat dikategorikan sebagai kelompok dhuafa. Hasil penelitian menunjukkan bahwa tiga variabel independen (karakteristik dasar pelanggan, referensi, pembayaran) berkorelasi negatif dengan variabel dependen. Namun, faktor tujuan tidak memiliki korelasi yang signifikan. Analisis kualitatif lebih lanjut juga menunjukkan bahwa baik manajemen bank maupun penerima qardhul hasan memiliki persepsi yang kurang tepat terhadap produk qardhul hasan. Pada gilirannya memperburuk NPL Qardhul-hasan.

Perbedaan peneliti sebelumnya dengan peneliti saat ini adalah peneliti terdahulu meneliti Evaluasi Non Performing Loan (NPL) Pinjaman Qardhul Hasan yang dipraktekkan Di BNI Syariah Cabang Yogyakarta, dimana manajemen bank maupun penerima qardhul hasan memiliki persepsi yang kurang tepat terhadap produk qardhul hasan. Pada gilirannya memperburuk NPL Qardhul-hasan. Sedangkan pada peneliti saat ini akad Qardhul Hasan yang di praktekkan pada Lembaga koperasi kelolaan DKM Mesjid ini hanya melihat kesesuaian antara teori dengan kondisi praktek yang nyata di Koperasi DKM, tidak meneliti lebih jauh terkait evaluasi performa pernyaluran pinjaman pada koperasi DKM.

\section{Qardhul Hasan dalam Persfektif Hukum} Islam pada Baitul Maal wa Tamwil (BMT) dan Implementasinya (Muhamad Bisri Mustofa and Mifta Khatul Khoir 2019)

Dalam pelaksanaan Lembaga Keuangan Syariah seperti Baitul Maal wa Tamwil (BMT) terdapat berbagai macam cara penghimpunan dana dan penyaluran dana. Penghimpunan dana dilakukan melalui simpanan wadie ah dan deposito. Sedangkan penyaluran dana dilakukan dengan pembiayaan murabahah, 
mudharabah musyarakah, rahn (gadai), ijarah, ijarah multijasa dan pembiayaan qardhul hasan. Pembiayaan Qardhul Hasan merupakan orientasi fungsi Lembaga Keuangan Syariah (Baitul Maal Wa Tamwil) sebagai lembaga sosial. Qardhul hasan adalah suatu pinjaman lunak yang diberikan atas dasar kewajiban sosial semata. Dalam hal ini peminjam tidak dituntut untuk mengembalikan apapun kecuali sejumlah yang dipinjamnya. Dalam pembiayaan Qardhul Hasan terdapat rukun dan syarat yaitu pelaku akad yang terdiri dari muqtaridh (peminjam), muqridh (pemberi pinjaman), qardh (dana),shighat yaitu ijab dan qabul kerelaan kedua belah pihak dan dana digunakan untuk sesuatu yang bermanfaat dan halal.Qardhul Hasan merupakan kegiatan untuk mencapai tujuan atau sasaran yang telah ditentukan terlebih dahulu oleh lembaga keuangan syariah yang bersangkutan. Mekanisme penerapan Qardhul Hasan semata-mata bertujuan untuk memberikan pertolongan guna memenuhi kebutuhan masyarakat kecil. Dengan demikian dapat diketahui bahwa bentuk peminjaman melalui Qardhul Hasan sudah sesuai dengan prinsip hukum ekonomi syariah, potensi sumber dana Qardhul Hasan ternyata cukup besar apabila dimanfaatkan dan dikelola secara optimal dan implementasinya sangat berguna bagi masyarakat.

Perbedaan peneliti sebelumnya dengan peneliti saat ini adalah peneliti terdahulu meneliti Qardhul Hasan dalam Persfektif Hukum Islam dan Implementasinya yang di praktekkan pada Lembaga Baitul Maal wa Tamwil (BMT). Sedangkan pada peneliti saat ini akad Qardhul Hasan yang di praktekkan pada Lembaga koperasi yang dikelola oleh DKM Mesjid, dimana secara kelembagaan koperasi DKM ini belum Syariah, karena masih menginduk ke Koperasi Desa setempat, akan tetapi pada prakteknya sudah mulai menggunakan prinsip-prinsip Syariah. Peneliti hanya meneliti kesesuaian antara teori yang digunakan dengan praktek di lapangan.

10. Implementasi Sifat Ta'awun Dalam Lembaga Keuangan Syariah Melalui Akad Al-Qardh (Rukiah 2019)

Tujuan dari penulisan artikel ini adalah untuk mengetahui konsep Al-qardh dalam lembaga keuangan syariah dari tinjauan fiqh, bagaimana kendala kendala pelaksanaan di lapangan, serta produk- produk apa saja yang memakai akad ini di lembaga keuangan. Metode analisis yang dipakai adalah kajian literatur dan temuan di lapangan. Hasil yang ditemukan adalah bahwa, akad qardh dalam prakteknya, belum maksimal dimanfaatkan lembaga keuangan untuk optimalisasi fungsi sosialnya, dan kurangnya kesadaran nasabah untuk mengembalikan hutang qardh, sebab adanya persepsi nasabah bahwa hutang qardh itu adalah dana kebajikan.

Perbedaan peneliti sebelumnya dengan peneliti saat ini adalah peneliti terdahulu meneliti Implementasi Sifat Ta'awun Dalam Lembaga Keuangan Syariah Melalui Akad Al-Qardh, artinya praktek akad Qardhul Hasan dijadikan sarana sifat tolong-menolong antara Lembaga keuangan dengan nasabah atau masyarakat. Sedangkan pada peneliti saat ini akad Qardhul Hasan yang di praktekkan pada Lembaga koperasi kelolaan DKM Mesjid, dimana secara kelembagaan koperasi DKM ini belum Syariah, karena masih menginduk ke Koperasi Desa setempat, akan tetapi pada prakteknya sudah mulai menggunakan prinsip-prinsip Syariah. Peneliti saat ini hanya meneliti kesesuaian antara teori yang digunakan dengan praktek di lapangan.

\section{METODOLOGI PENELITIAN}

Metode yang digunakan dalam penelitian ini adalah metode kualitatif. Dengan 
menggunakan metode ini, peneliti dapat memaparkan (mendeskripsikan) maupun memberikan gambaran suatu satuan analisis secara utuh yang terintegritas. Dalam metode ini satuan analisis yang dimaksud berupa satuan penellitian yang dilakukan secara intensif, terinci dan mendalam terhadap suatu organisasi, Lembaga (Arikunto 2013).

Lokasi penelitian yang dilakukan di Koperasi Dewan Kemakmuran Masjid AtTaqwa Cicadas Sagalaherang Kabupaten Subang, guna memperoleh data data terkait dengan penelitian yang penulis kaji mengenai praktek- praktek akad Qardun hasan Di Koprasi Dewan Kemakmuranmasjid AtTaqwa Cicadas Sagalaherang Kabupaten Subang.

Adapaun jenis data yang digunakan dalam penelitian ini adalah data primer dan data sekunder, yang menjadi sumber data primer dalam penelitian ini yaitu wawancara yang diperoleh dari ketua dan anggota Koprasi Dewan Kemakmuran Masjid At-Taqwa Cicadas Sagalaherang Subang. Sedangkan data sekunder dalam penelitian ini adalah buku-buku dan karya ilmiah yang terkait dengan penelitian pelaksanaan Prakter Akad Qardun Hasan Di Koprasi Dewan Kemakmuranmasjid At-Taqwa Cicadas Sagalaherang Kabupaten Subang.

\section{HASIL DAN PEMBAHASAN}

\section{A. Ketentuan dan Pelaksanaan \\ Pembiayaan Akad Qardhul Hasan Di Koperasi Dewan Kemakmuran Masjid At-Taqwa Cicadas Sagalaherang Subang}

Qardhul Hasan merupakan pembiayaan dengan akad ibadah, dimana tujuan utamanya adalah membantu anggota dalam mengembangkan usahanya sehingga dapat terbentuk sebuah semangat wirausaha dalam sektor industri mikro, yang pada akhirnya akan memacu percepatan ekonomi kerakyatan berbasiskan syariah. Hal tersebut sesuai dengan teori Qardhul Hasan yang dikemukakan Antonio mengenai pemberian harta kepada orang lain yang dapat ditagih atau diminta kembali atau dengan kata lain meminjamkan tanpa mengharapkan imbalan (Muhammad Syafi'i Antonio 2001). Faktor utama anggota melakukan pembiayaan Qardhul Hasan adalah karena adanya kemudahan nasabah dalam peminjaman dan faktor utama yang kedua adalah karena tidak adanya jaminan dan bunga dalam upaya meringankan beban orang yang kesulitan membayar pinjaman dapat dilakukan dalam bentuk memberikan tanggungan maupun menghapus pinjaman. Hal tersebut sesuai dengan Perintah Allah yang terdapat pada surah Al Baqarah ayat 24-52, ayat tersebut menjelaskan memberikan pilihan kita sebagai manusia yang berjiwa sosial untuk membantu sesama muslim dalam hal meringankan beban hidup dengan memberikan pinjaman dengan niat yang ihklas. Dalam ayat tersebut Allah menjanjikan akan memberikan atau melipatgandakan apa yang telah kita berikan kepada orang lain.

Prinsip ini yang digunakan oleh Koperasi Dewan Kemakmuran Masjid At-Taqwa Cicadas Sagalaherang Subang dalam memberikan pinjaman Qardhul Hasan pada anggota pelaku usaha mikro. Hasil penelitian yang diperoleh dari hasil wawancara dengan Bapak Haerin selaku Ketua Koperasi DKM At-Taqwa Cicadas Sagalaherang Subang sesuai dengan teori yang dikemukakan oleh Antonio yaitu dana yang telah disalurkan kepada anggota terutama pengusaha mikro, maka anggota memiliki kewajiban untuk mengembalikan angsurannya tanpa adanya penambahan bagi hasil (Muhammad Syafi'i Antonio 2001). Ketentuan mengangsurnya ditetapkan pada akad yang telah ditandatangani sebelum pencairan dana. 
Meskipun sudah ditetapkan namun dalam hal mengangsur pembiayaan Qardhul Hasan di Koperasi DKM At-Taqwa Cicadas Sagalaherang Subang masih bersifat fleksibel maksudnya bisa dianggsur tanggal berapapun setiap bulannya dan apabila mengalami keterlambatan mengangsur juga tidak dikenai denda oleh pihak Koperasi DKM At-Taqwa Cicadas Sagalaherang Subang. Hal tersebut juga didukung oleh Wardi yang mendefinisi Qardhul Hasan dengan titik tekan pada kemampuan. Artinya pengembalian pinjaman dalam pembiayaan Qardhul Hasan benarbenar melihat kemampuan dari si peminjam (Muslich 2010). Kita juga mengatahui bahwa kategori peminjam untuk pembiayaan Qardhul Hasan memang diutamakan pelaku usaha mikro. Jika anggota pembiayaan Qardhul Hasan memang tidak mampu mengembalikan maka pihak lembaga juga tidak boleh memaksa untuk dikembalikan. Tahapan selanjutnya dari proses pembiayaan adalah syarat-syarat yang harus dipenuhi oleh calon pemohon pembiayaan.

Di Koperasi DKM At-Taqwa Cicadas Sagalaherang Subang persyaratan untuk melakukan pembiayaan Qardhul Hasan adalah mengisi formulir pembiayaan, menyetorkan fotocopy KTP calon anggota, fotocopy KTP istri/suami dan Fotocopy KK, menyetorkan simpanan pokok Rp.100.000;, menyetorkan simpanan wajib Rp.500.000; dapat diangsur maksimal selama 6 bulan (selanjutnya minimal Rp.20.000; per bulan), dan membayar administrasi keanggotaan Rp.25.000;. Adapun sebagian dana yang di terima oleh DKM At-Taqwa adalah dari koperasi BUMDesa (koperasi usaha), dana yang dikeluarkan oleh koperasi sebesar $2 \%$ pertahun.

Persyaratan pembiayaan ini selaras dengan penelitian terdahulu yang ditulis oleh Pitaloka Dalam tulisannya mengungkapkan bahwa persyaratan untuk pembiayaan Qardhul
Hasan adalah melampirkan fotocopy KTP suami dan istri, fotocopy Kartu Keluarga (KK), fotocopy Kartu Nikah, fotocopy rekening listrik Persyaratan administrasi memang hal yang wajib dilampirkan oleh pemohon pembiayaan, namun mengenai persyaratan juga tergantung oleh lembaga masing-masing (Wijaya 2017). Setelah melakukan pengajuan, maka di Koperasi DKM At-Taqwa Cicadas Sagalaherang Subang akan melakukan survey yang dilakukan oleh bagian pembiayaan. Dalam melakukan survey diharapkan Koperasi DKM At-Taqwa Cicadas Sagalaherang Subang mengetahui kondisi sebenarnya dari pemohon pembiayaan sehingga nanti proses penggunaan dan pengembalian dana Qardhul Hasan dapat dipertanggungjawabkan. Dalam survey ini nantinya yang menentukan anggota bisa mendapat pencairan dana Qardhul Hasan atau tidak. Koperasi DKM At-Taqwa sendiri pada proses survey ini juga menentukan apakah nantinya pemohon pembiayaan akan diminta untuk menyerahkan jaminan atau tidak jika permohonan pembiayaannya dikabulkan meskipun dalam kategori pembiayaan Qardhul Hasan (Haeri 2019).

Prinsip analisis pembiayaan yang dilakukan Koperasi DKM At-Taqwa adalah prinsip 5C yaitu character, capacity, capital, collateral dan condition of economy. Analisis ini didukung oleh teori Antonio yang bertujuan untuk menilai kelayakan pemohon serta untuk menghindari tidak terbayarnya pembiayaan.

\section{B. Kendala yang dihadapi Koperasi DKM At-Taqwa Cicadas Sagalaherang Subang dalam memberikan pembiayaan Qardhul Hasan.}

Dalam melakukan pembiayaan pastinya ada kendala yang dialami oleh Koperasi DKM AtTaqwa Cicadas Sagalaherang Subang termasuk dalam memberikan pembiayaan Qardhul Hasan. Terdapat dua faktor kendala 
pembiayaa Qardhul Hasan yaitu faktor internal dan eksternal.

\section{Kendala Internal}

Dana pembiayaan Qardhul Hasan masih terbatas Faktor internal diantaranya adalah mengenai dana yang tersedia untuk pembiayaan Qardhul Hasan masih terbatas, sedangkan permintaan pembiayaan Qardhul Hasan bisa dibilang cukup banyak (Haeri 2019). Faktor tersebut diatas menjadi penghambat bagi Koperasi dalam menyalurkan dana, karena Qardhul Hasan tidak menggunakan profit atau bagi hasil, dan dana Qardhul Hasan yang dikembalikan akan dipinjamkan lagi kepada anggota lain.

Pembiayaan macet Kendala internal berikutnya yang dialami Koperasi DKM AtTaqwa Cicadas Sagalaherang Subang adalah anggota yang gagal bayar atau pembiayaan macet. Kurangnya kesadaran anggota untuk membayar tanggungan pembiyaan yang diberikan oleh Koperasi DKM At-Taqwa menjadi penyebab terjadinya pembiayaan macet. Hal ini sejalan dengan teori yang diungkapkan oleh Renny mengenai pembiayaan macet terjadi akibat penyimpangan pembayaran pembiayaan yang dilakukan penerima pembiayaan (Supriyatni 2006). Kendala pembiayaan macet memang menjadi faktor utama berkurangnya ketersediaan dana pembiayaan Qardhul Hasan.

\section{Kendala Eksternal}

Anggota menyalahgunakan dana yang telah diberikan Dana pembiayaan Qardhul Hasan di Koperasi DKM At-Taqwa memang difokuskan untuk membantu pelaku usaha mikro dalam mengembangkan usahanya. Tetapi sebagian anggota pembiayaan menurut Bapak Haeri masih menyimpang dan menggunakan dana tersebut untuk kepentingan yang tidak berkaitan dengan pengembangan usaha (Haeri 2019). Penyalahgunaan dana memang akan mengakibatkan tidak tercapainya tujuan utama dari pembiayaan Qardhul Hasan yang memang ditujukan untuk peningkatan kesejahteraan usaha mikro.

Kurangnya pengalaman anggota dalam berwirausaha Sedangkan kendala ekternal lainnya adalah anggota kurang pengalaman dalam berwirausaha. Pembiayaan Qardhul Hasan di Koperasi DKM At-Taqwa Cicadas Sagalaherang Subang memang dikhusukan untuk para wirausaha pada tingkatan usaha mikro. Tetapi beberapa anggota pembiayaan masih terkendala dengan kurangnya wawasan dalam berwirausaha yang akan berdampak pada pengembangan usahanya. Hal tersebut seperti yang dialami salah satu anggota pembiayaan, Ibu Jurinah mengungkapkan kesulitan dalam masalah pemasaran produknya sehingga usahanya sulit berkembang dan kurang produktif (Haeri 2019). Pembiayaan Qardhul Hasan harusnya memang ditujukan untuk mendanai usaha mikro yang tergolong produktif dan dapat berkembang agar menunjang kesejahteraan pelaku usaha mikro.

\section{C.Solusi yang dilakukan Koperasi DKM At-Taqwa Cicadas Sagalaherang Subang terhadap kendala dalam pemberian pembiayaan Qardhul Hasan}

Dari setiap kendala yang dialami pastinya ada solusi untuk memececahkan masalah yang terjadi, khususnya solusi pembiayaan Qardhul Hasan di Koperasi DKM At-Taqwa Cicadas Sagalaherang Subang. Solusi mengenai masalah internal dan eksternal dari Koperasi DKM At-Taqwa Cicadas Sagalaherang Subang antara lain :

1. Solusi Kendala Internal

Kurangnya Ketersediaan Dana Sumber dana Qardhul Hasan di Koperasi DKM AtTaqwa Cicadas Sagalaherang Subang berasal 
dari infaq anggota Koperasi DKM At-Taqwa Cicadas Sagalaherang Subang. Karena bersifat dana sosial maka pengelolaannya harus benar-benar diperhatikan. Disinilah dituntut supaya manajemen Baitul Maal wa Tamwil ditata secara profesional.

Kendala pembiayaan macet yang dilakukan Koperasi DKM At-Taqwa Cicadas Sagalaherang Subang diantaranya adalah perpanjangan waktu pengembalian angsuran bagi anggota yang telat membayar, petugas akan mengingatkan dengan cara memberitahu via sms, telepon, petugas akan mendatangi langsung anggota yang akan membayar angsuran. petugas akan memberikan binaan dan arahan dalam mengelola dana. Solusi lain pada anggota tidak mampu membayar angsuran sesuai perhitungan yang semestinya, pihak Koperasi akan mengurangi jumlah angsuran setiap bulannya.

\section{Solusi Kendala Eksternal}

Solusi Penyalahgunaan Dana oleh anggota Solusi yang diterapkan Koperasi DKM AtTaqwa Cicadas Sagalaherang Subang untuk anggota yang menyimpang dalam penggunaan dana yang adalah lebih selektif dalam hal pemilihan calon anggota pembiayaan, melakukan pembinaan ulang kepada anggota yang sudah terlanjur menggunakan dana tersebut. Sehingga selektifitas dalam pemilihan anggota penerima pembiayaan Qardhul Hasan harus lebih diperhatikan oleh pihak Koperasi DKM At-Taqwa Cicadas Sagalaherang Subang.

Solusi Kurangnya Wawasan Berwirausaha Anggota, solusi yang diterapkan Koperasi DKM At-Taqwa Cicadas Sagalaherang Subang terkait kendala kurangnya wawasan anggota dalam berwirausaha diungkapkan Bapak Haerin dengan aktif memberikan pembinaan sebelum dana pembiayaan diberikan kepada anggota (Haeri 2019). Pengawasan terhadap usaha yang dijalankan anggota memang diperlukan agar dana pembiayaan Qardhul Hasan yang ditujukan untuk pengembangan usaha dapat sesuai dengan yang diharapkan.

\section{D.Perspektif Ekonomi Syariah Pada Praktek Qardhul Hasan Di Koperasi DKM At-Taqwa Cicadas Sagalaherang Subang}

Dalam ayat Al-Qur'an telah dijelaskan bahwa sesama manusia harus saling tolong menolong dalam hal kebaikan sesuai yang difirmankan Allah SWT dalam Q.S al-Maidah ayat 2 :

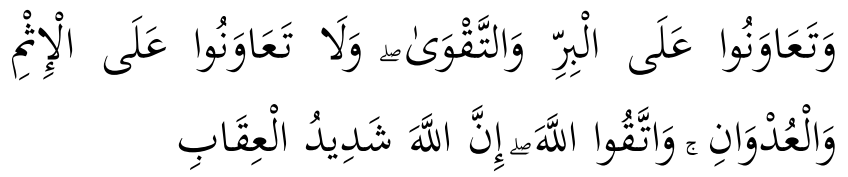

"Dan tolong-menolonglah kamu dalam (mengerjakan) kebajikan dan taqwa, dan jangan tolong menolong dalam berbuat dosa dan permusuhan".

Pada bagian ini penulis mencoba menganalisis tinjauan hukum Islam terhadap praktek Qardhul Hasan di Koperasi DKM AtTaqwa Cicadas Sagalaherang Subang. Qardhul Hasan dalam Fiqh dengan pelaksanaannya di Koperasi DKM At-Taqwa Cicadas Sagalaherang Subang, Penulis telah memaparkan bahwa Qardhul Hasan hukumnya boleh (jaiz) apabila telah memenuhi syarat dan rukun yang telah di tentukan, yaitu : muqrid dan muqtarid harus memiliki kecakapan untuk melakukan muamalah, Ma'qud alaih, yaitu uang atau barang ada uang yang dipinjamkan atau objek akad dalam Qardhul Hasan, Dan Shighat, yaitu ijab dan qabul Qardh adalah suatu akad kepemilikan atas harta. Oleh karena itu, akad tersebut tidak sah kecuali dengan adanya ijab dan qabul.

Jadi praktek Qardhul Hasan di Koperasi DKM At-Taqwa Cicadas Sagalaherang Subang secara rukun dan syaratnya sudah sesuai yaitu muqrid dan muqtarid semua

EKSISBANK (Ekonomi Syariah dan Bisnis Perbankan), Volume 5, Nomor 1, Juni 2021 
cakap dalam melakukan muamalah. Ada yang dijadikan objek Qardhul Hasan (uang) serta ada ijab dan qabul.

Adapun Rukun qardh (Hutang-piutang) ada 4 macam yaitu: Pemilik barang (muqridh), yang mendapat barang atau peminjam, (muqtaridh) serah terima (ijab qabul), dan barang yang dipinjamkan (qardh) (Halilah 2019).

Muqridh disyaratkan harus orang yang dibolehkan melakukan tasarruf atau memiliki ahliatul ada. Oleh karena itu, qardh tidak sah apabila dilakukan oleh anak yang masih dibawah umur atau orang gila (Muslich 2010).

Ijab dan Qabul (shighat)

Shighat ijab bisa dengan menggunakan lafal qardh (utang atau pinjam) dan salaf (utang), atau dengan lafal yang mengandung arti kepemilikan. Akad qardh tidak sah kecuali dengan adanya ijab dan qabul.

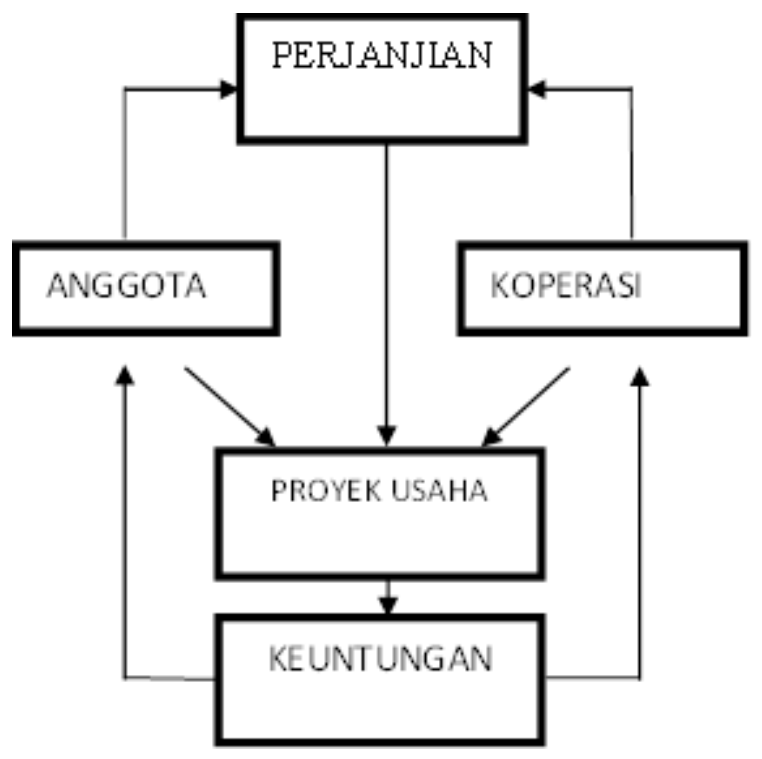

Pinjaman Qardhul Hasan yang dilakukan oleh Koperasi Dewan Kemakmuran Masjid At-Taqwa Cicadas Sagalaherang Subang pada anggota pelaku usaha mikro. Hasil penelitian yang diperoleh dari hasil wawancara dengan Bapak Haerin selaku Ketua Koperasi DKM At-Taqwa Cicadas Sagalaherang Subang sesuai dengan teori yang dikemukakan oleh Antonio yaitu dana yang telah disalurkan kepada anggota terutama pengusaha mikro, maka anggota memiliki kewajiban untuk mengembalikan angsurannya tanpa adanya penambahan bagi hasil (Muhammad Syafii Antonio 2001). Ketentuan mengangsurnya ditetapkan pada akad yang telah ditandatangani sebelum pencairan dana.

Koperasi DKM At-Taqwa Cicadas Sagalaherang Subang tidak menetapkan denda apabila mengalami keterlambatan mengangsur dikarenakan beberapa kendala.

\section{E. Dampak Praktek Akad Qardhul Hasan Terhadap Masyarakat Di Desa Cicadas Kecamatan Sagalaherang Kabupaten Subang}

Terdapat beberapa dampak positif dan negatif dalam pembiayaan Qardhul Hasan di Koperasi DKM At-Taqwa Cicadas Sagalaherang Subang. Dampak positifnya yaitu masyarakat merasa terbantu akan adanya pembiayaan Qardhul Hasan ini karena berkat adanya pinjaman pembiayaan ini masyarakat bisa mempunyai modal usaha untuk memperkuat usahanya. Anggota juga dapat menggunakan pinjaman tersebut untuk biaya sekolah, kesehatan ataupun yang lainnya.

Sedangkan dampak negatifnya yaitu pihak Koperasi DKM At-Taqwa Cicadas Sagalaherang Subang kurang tegas terhadap sanksi yang diberikan kepada anggota sehingga anggota lalai untuk membayar angsuran dan itu menjadi salahsatu penghambat pembiayaan kepada anggota lainnya. Kemudian dikarenakan pembiayaan Qardhul Hasan ini merupakan akad tabarru atau saling tolong menolong, seringkali terdapat suatu kelompok masyarakat atau individu yang menyalahgunakan dan memanfaatkan keadaan tersebut untuk mencari keuntungan. 


\section{KESIMPULAN}

Dari hasil penelitian Pembiayaan Qardhul Hasan di Koperasi DKM At-Taqwa Cicadas Sagalaherang Subang dapat ditarik kesimpulan bahwa pembiayaan yang telah disalurkan kepada anggota terutama pengusaha mikro, maka anggota memiliki kewajiban untuk mengembalikan angsurannya tanpa adanya penambahan. apabila mengalami keterlambatan mengangsur juga tidak dikenai denda oleh pihak Koperasi DKM At-Taqwa Cicadas Sagalaherang Subang. kendala yang dialami oleh Koperasi DKM At-Taqwa Cicadas Sagalaherang Subang dalam memberikan pembiayaan Qardhul Hasan adalah pembiayaan macet, kurangnya kesadaran anggota untuk membayar tanggungan pembiyaan yang diberikan oleh Koperasi DKM At-Taqwa menjadi penyebab terjadinya pembiayaan macet. Selain karena anggota yang lalai, ada faktor lain yang membuat pembiayaan macet yaitu karena kurangnya pengarahan dan bimbingan dari pihak Koperasi itu sendiri kepada pelaku usaha mikro sehingga berdampak pada penghasilan yang ia dapatkan, hal ini membuat anggota kesulitan untuk membayar angsuran.

Tinjauan ekonomi Syariah terhadap pelaksanaan Qardhul Hasan di Koperasi DKM At-Taqwa Cicadas Sagalaherang Subang sudah sesuai dengan ekonomi syariah, pembiayaan Qardhul Hasan hukumnya boleh (jaiz) apabila telah memenuhi syarat dan rukun yang telah di tentukan dan dalam praktek Qardhul Hasan di Koperasi DKM AtTaqwa, pemberi pinjaman (muqrid) tidak menarik keuntungan dari yang berhutang. Jadi praktek Qardhul Hasan di Koperasi DKM AtTaqwa Cicadas Sagalaherang Subang secara rukun dan syaratnya sudah sesuai yaitu muqrid dan muqtarid semua cakap dalam melakukan muamalah, ada yang dijadikan objek Qardhul Hasan (uang) serta ada ijab dan qabul.

Terdapat dampak positif dan negatif dalam pembiayaan Qardhul Hasan di Koperasi DKM At-Taqwa Cicadas Sagalaherang Subang. Dampak positifnya yaitu masyarakat merasa terbantu akan adanya pembiayaan Qardhul Hasan ini karena berkat adanya pinjaman pembiayaan ini masyarakat bisa mempunyai modal usaha untuk memperkuat usahanya. Sedangkan dampak negatifnya yaitu pihak Koperasi DKM At-Taqwa Cicadas Sagalaherang Subang kurang tegas terhadap sanksi yang diberikan kepada anggota sehingga anggota kurang memperhatikan angsuran yang harus dibayar dan itu menjadi salah satu penghambat pembiayaan kepada anggota lainnya.

\section{DAFTAR PUSTAKA}

Adnan, Muhammad Akhyar, and Firdaus Furywardhana. 2006. "Evaluasi Non Performing Loan (NPL) Pinjaman Qardhul Hasan (Studi Kasus Di BNI Syariah Cabang Yogyakarta)." Jurnal Akutansi dan Auditing Indonesia 10(2): 155-71.

Antonio, Muhammad Syafi'i. 2001. Bank Syariah Dari Teori Ke Praktik. Jakarta: Gema Insani Press.

Antonio, Muhammad Syafii. 2001. Bank Syariah: Dari Teori Ke Praktek. Jakarta: Gema Insani.

Arief, Yoyok Suyoto. 2012. “Akad Qordhul Hasan Sebagai Sarana Pelaksanaan CSR Pada Perbankan Syariah." Ijtihad: Jurnal Hukum dan Ekonomi Syariah 6(2).

Arikunto, Suharsimi. 2013. Prosedur Penelitian Suatu Pendekatan Praktek. 1st ed. Jakarta: Rineka Cipta.

Az-zarqa, Az-zarqa, and Naning Nur Hidayah. 2018. 10 Az Zarqa': Jurnal Hukum Bisnis 
Islam Infak Sebagai Program Pengurangan Ketergantungan Masyarakat Terhadap Rentenir (Studi Kasus Pada BAZNAS Kabupaten Ngawi). http://202.0.92.5/syariah/azzarqa/article/ view/1739 (November 9, 2020).

Efendi, Rustam, and Boy Syansul Bakhri. 2018. "Konsep Koperasi Bung Hatta Dalam Perspektif Ekonomi Syariah." ALHIKMAH: Jurnal Agama Dan Ilmu Pengetahuan 15(1).

Faujiah, Ani. 2020. "Praktek Akad Qardhul Hasan Pada Bank Wakaf Mikro." ACTIVA: Jurnal Ekonomi Syariah 3(1): 72-89.

Haeri. 2019. "Praktek Akad Qardhul Hasan Di Koperasi Dewan Kemakmuran Masjid At-Taqwa Desa Cicadas Sagalaherang Kabupaten Subang."

Halilah, M. Syaikhul Arif Siti. 2019. "Kafalah Dalam Pandangan Islam." Siyasah: Jurnal Hukum Tata Negara 2(2). www.ejournal.annadwahkualatungkal.ac .id (May 31, 2021).

Hamidah, Idah, Jalaludin, and Ahmad Damiri. 2019. "Analisis Tabungan Paket Lebaran Dalam Persfektif Ekonomi Syari'ah Di Desa Parung Kecamatan Subang Kabupaten Subang." Eksisbank 3(2): $148-53$.

Lestari, Rina. 2020. "Pelaksanaan Bagi Hasil Simpanan Dan Pembiayaan Mudharabah Di BMT Al-Amanah Cabang Subang." EKSISBANK: Ekonomi Syariah dan Bisnis Perbankan 4(1): 32-38. http://www.journal.stiespurwakarta.ac.id/index.php/EKSISBAN K/article/view/92 (October 28, 2020).

Ma'rifahYuliani. 2019. "Konsep Divisi Ekonomi Masjid Berbasis Teknologi Industri 4.0." Jurnal Al Qardh 4(2): 99114.
Muhamad Bisri Mustofa, and Mifta Khatul Khoir. 2019. "Qardhul Hasan Dalam Persfektif Hukum Islam Pada Baitul Maal Wa Tamwil (BMT) Dan Implementasinya." At Taajir: Jurnal Ekonomi, Bisnis dan Keuangan Syariah 1(1): 44-58. http://journal.iaiagussalimmetro.ac.id/index.php/attaajir/ article/view/27.

Muslich, Ahmad Wardi. 2010. Fiqh Muamalat. 1st ed. Jakarta: Amzah.

Purwadi, M. Imam. 2011. "Qardh Al-Hasan Dalam Perbankan Syariah : Konsep Dan Implementasinya Berdasarkan Prinsip Manfaat Bagi Pemberdayaan Masyarakat." UNISIA: Jurnal Ilmu-ilmu Sosial 33(74): 141-54.

Qardhawi, Yusuf. 1993. Fatwa-Fatwa Kontemporer I. Jakarta: Gema Insani Press.

Rozalinda. 2016. Fikih Ekonomi Syariah Prinsip Dan Implementasinya Pada Sektor Keuangan Syariah. Jakarta: Raja Grafindo Persada.

Rukiah, Rukiah. 2019. "Implementasi Sifat Ta'awun Dalam Lembaga Keuangan Syariah Melalui Akad Al-Qardh." Studi Multidisipliner: Jurnal Kajian Keislaman 6(1): 87-103. http://jurnal.iainpadangsidimpuan.ac.id/index.php/multd/ article/view/1751.

Solekha, Yasmin Afnan, Alisa Qotrunnada Murdianah, Nofia Sri Lestari, and Rinda Asytuti. 2021. "Baitul Maal Wa Tamwil Sebagai Lembaga Keuangan Mikro Syariah Pemberdaya Ekonomi Umat (Konsep Dan Teori)." Velocity: Journal Of Sharia Finance And Banking 1(1): 44-58.

Supriyatni, Renny. 2006. Model Alternative Mediasi Syariah Dalam Penyelesaian

EKSISBANK (Ekonomi Syariah dan Bisnis Perbankan), Volume 5, Nomor 1, Juni 2021 
Perbankan Syariah. Jakarta: Mitra Wacana Media.

Suryadi, Nanda, and Yusmila Rani Putri. 2018.

"Analisis Penerapan Pembiayaan

Qardhul Hasan Berdasarkan Psak

Syariah Pada BMT Al Ittihad Rumbai

Pekanbaru." Jurnal Tabarru': Islamic

Banking and Finance 1(1): 37-50.

https://journal.uir.ac.id/index.php/tabarr

u/article/view/2043.

Suskendariani, N N T. 2019. "Perlindungan

Hukum Bagi Penerima Waralaba

(Franchisee) Dalam Perjanjian

Waralaba." ... Ilmu Sosial Dan

Humaniora 2: 176-86.

http://jayapanguspress.penerbit.org/inde

x.php/ganaya/article/view/185.

Wijaya, Chusnul Pitaloka Kusuma. 2017.

"Analisis Pembiayaan Qardhul Hasan

Dalam Peningkatan Usaha Kecil Pada

BMT Muamalat Jumapolo." Institut

Agama Islam Negeri Surakarta. 